\title{
Uses and Conservation of Plant Species in a National Park-A Case Study of Ben En, Vietnam
}

\author{
Sam Van Hoang ${ }^{2,3}$, Pieter Bahs ${ }^{* 3}$, and Paul J. A. Kebler ${ }^{4}$ \\ ${ }^{2}$ Forest Plant Department, Vietnam Forestry University, Xuan Mai Hanoi, Vietnam \\ ${ }^{3}$ National Herbarium of the Netherlands, Leiden University Branch, Einsteinweg 2, P.O. Box 9514 , \\ 2300 RA, Leiden, The Netherlands \\ ${ }^{4}$ Hortus Botanicus Leiden, Binnenvestgracht 8, P.O. Box 9516, 2300 RA, Leiden, The Netherlands \\ *Corresponding author; e-mail: Baas@nhn.leidenuniv.nl
}

\begin{abstract}
Uses and Conservation of Plant Species in a National Park-A Case Study of Ben En, Vietnam. This paper surveys the use of wild and cultivated plants by local people in Ben En National Park, Vietnam, and analyzes its impact on the conservation status of some of the utilized species. A total of 208 species used for a range of nonmedicinal purposes are listed. See Hoang et al. (2008a) for 230 medicinal plants used in the park. Most species are used for food. The use of plants contributes very significantly to the livelihood of local people in the park, but the current use patterns are not sustainable and would lead to local extinction of rare and endangered species if no additional conservation measures are introduced. Men collect nonmedicinal plants more often than women. A total of 38 useful plant species are commercialized, and contribute $12 \%$ of the average income of individual households. Bamboo shoots of Schizostachyum funghomii (Poaceae) are the most important for income generation. The monetary equivalent of noncommercialized useful plants probably far exceeds the value of the traded plant products. Plant use is independent of the ethnicity of the different populations living in the park. Larger households make use of a greater variety of useful plant species than small families. Abundant species in the forest have a higher use index (UI) than less common species. Out of the 208 useful species, as many as 27 were found to be endangered locally, many more than the 11 or 8 endangered species included in national or global red lists. Currently, useful plants, especially important timber trees, are more abundant in the less disturbed parts of the park, far away from the villages, indicating the pressures of illegal logging and harvesting near villages on the ecosystems.
\end{abstract}

Key Words: Useful plants, Ben En National Park, food plants, construction, firewood, household tools, conservation, Use Index.

\section{Introduction}

Ben En National Park is one of 30 national parks in Vietnam, established in 1992 to conserve the rich, but seriously threatened, biodiversity of the country. The Ben En area was designated for the protection of fauna in 1979, and as a nature reserve in 1986, although commercial logging operations continued until 1992. The park is inhabited by 4,000 local people belonging to five ethnic groups. Although initially all uses of wild natural resources were forbidden in the national

Received 10 March 2008; accepted 17 September 2008; published online 25 November 2008. parks, current policies in Vietnam seek to find an optimal and realistic balance between conservation and sustainable use of natural resources in these parks. Apart from very preliminary species surveys (Anonymous 2000; Todoff et al. 2000), very little is known of either the plant biodiversity or the ethnobotany of Ben En. The current study of native and cultivated plant use in the park forms part of a larger study including traditional medicinal plant use (Hoang et al. 2008a) and detailed botanical plot studies analyzing the effect of selective harvesting of NTFP and of illegal logging on the plant species diversity within the park (Hoang et al. 2008b; Hoang et al. in preparation). This knowledge is crucial for the development of a 
sound management policy that is aimed both at nature conservation and at improving the livelihood of the local communities within the park.

The commercial extraction of useful plants as a conservation strategy is based on the argument that forest conservation must be able to offer economic incentives to local rural people in order to counter the threat of destructive land uses such as logging, shifting cultivation, and cattle ranching (Amacher 2002; Nepstad and Schwartzman 1992; Panayotou and Ashton 1992). However, the growing commercial trade of natural products, in particular medicinal plants and woodcrafts, has resulted in increasing exploitation of wild plant populations (Lange 1998), and this has generated concern about threats for local extinction (Clay 1997; Cunningham 2001; Tiwari 2000).

Specific research questions of the present study are these: 1) Which plant species are used for which purpose? 2) Which species are commercialized? 3) What is their relative importance for the local communities based on a use index and on monetary revenues from commercialized species? 4) What is the impact of local people on these useful plants in the wild? and 5) How do factors such as ethnicity, size of each household, and species density in the park affect plant use?

It is hoped that the answers to these questions can serve to model management strategies in other national parks in Vietnam and elsewhere and contribute to the conservation of both cultural and plant diversity.

\section{Methodology}

\section{ETHNOBOTANICAL INVENTORY}

Household surveys and interviews were carried out in 45 randomly-selected households per village (out of a total of about 110-150 households per village) during a 6-month field survey held from October 2005 to March 2006 by the senior author and four students. The standard interviews contained specific questions on age, gender, and ethnic background of the gatherers and main users of plant products. Additionally, we used the "walk-in-the-wood" method (Prance et al. 1987) to determine which products are harvested (and for what purpose) in the forests surrounding the villages. These trips were also used to collect voucher specimens for reliable identification of the harvested plants. Special collecting trips were organized with local experts, for instance, people usually collecting useful plants, or locals with a detailed knowledge of plants. Furthermore, several companies making furniture in and around the research area were visited to determine which timber species were used and from which sources they came. Local names were noted during these surveys as recommended by Martin (1995). Most information was double-checked with different informants and with manuals such as the Flora of Vietnam (Ho 2000), the manual on non-timber forest products in Vietnam (Hung 2007), and the PROSEA Handbooks (1989-2003). Market inventories were used to determine the price of the forest products. These served as an independent way to determine which products are harvested from the surrounding forest. We also assessed local uses of these forest products.

All plants that were considered by local people to have useful properties were collected and identified. These plants included not only wild species but also cultivated plants and wild plants that had been taken from the forest and planted in gardens or agricultural fields. One herbarium voucher of each specimen was deposited in the herbarium of the Vietnam Forestry University; additional vouchers were sent to the National Herbarium of the Netherlands (L) and specialists elsewhere for identification

The importance of useful plant species was identified using standard Participatory Rural Appraisal (PRA) techniques (PID and NES 1989; Ngai 2001), whereby local people were asked to rank a list of regularly-used plants. We also quantified the relative use of species by calculating a Use Index (UI) based on the proportion of households utilizing a given species (see below).

The relative importance of timber species was assessed using three criteria: (1) ranking of species from a given list by forest rangers of Ben En National Park, who were asked how often certain illegally-harvested species were confiscated from local people both inside and outside the park; (2) proportion of listed species harvested by local people; and (3) frequency of tree stumps found during the field inventory. Stumps were identified by leaves and fruits or flowers left in the forest when the timber trees had been felled very recently, or from sucker shoots which emerged when the trees had been felled a long time ago. Bark characters were also used to identify the stumps. Additionally, local informants with expertise in tree (and stump) identification assisted us. 
The market demand, intensity of collection and abundance in the wild were classified as low, medium, or high (based on the interviews with local people and by using PRA techniques).

Plants were divided into five end-use categories, largely following Prance et al. (1987):

a. Food: Any plant or plant part (fruits, seeds, leaves, bark, flowers, or latex) used for human consumption.

b. Construction: All roundwood and sawn boards used for house frames, furniture, canoes, and bridges.

c. Household tools and related products: All plants or plant parts used for house equipment, handicrafts, tools, poisons, shampoo, candles.

d. Medicine (see Hoang et al. 2008a)

e. Firewood: All plants that are used for firewood, including charcoal.

f. Others: Plants used as ornamentals, wrapping material, or pulp and paper.

Plants with multiple uses fall into more than one category.

\section{Plot InVentory}

For a detailed analysis of plant biodiversity patterns in the park (Hoang et al. 2008b), and to study the impact of local people on collecting useful plants in the wild (this study), we established 41 transects, $200 \mathrm{~m}$ long, at $250 \mathrm{~m}$ intervals at right angles to and along the old logging road from Song Chang forest ranger station to Cong Troi. The total length of these transects combined is ca. $7.4 \mathrm{~km}$. We also established four $10 \times 10 \mathrm{~m}$ plots at $50 \mathrm{~m}$ from the logging road and at $40 \mathrm{~m}$ forward intervals on each transect, resulting in ca. 147 plots for all transects combined (in some transects we were not able to establish 4 plots, because of steep, inaccessible limestone slopes). In each plot of $10 \times$ $10 \mathrm{~m}$, all trees with a dbh $\geq 5 \mathrm{~cm}$ were identified. In this study, we combined 4 plots in each transect into 1 larger plot (we use the term "0.04 ha plot" for these combined plots). We also established 6 transects to cover the rest of the park, with a total length of about $26 \mathrm{~km}$. In each transect we noted all species and collected specimens of plants which could not be identified in the field. In all 6 transects, we established 30 random plots of $10 \times 10 \mathrm{~m}$ and identified all species in the plots. Furthermore we also collected many plants outside the plots and transects, to make sure that our inventory was as representative as possible of the entire species richness of the local flora.

\section{Data Analysis}

The database resulting from the ethnobotanical inventory was used to calculate a use index (UI) for each species by using the following equation: $U I=U s / N$, where Us is the number of households which mentioned a use for species $s$, and $\mathrm{N}$ is the total of households that were interviewed in the research area. This Use Index is a modification of the Use Value (UV), introduced by Phillips and Gentry (1993) and recently used by De Lucena et al. (2007), which is calculated from the relative number of times a species is mentioned by various informants in ethnobotanical inventories.

Simple regression analysis (SPSS 16.0) was used to examine whether the number of stumps and distances from villages to plots relate to number of useful plants and number of important timber trees, the relation between Use Index and number of useful plant species and number of important timber trees in plots, and the number of people in each household and number of useful plant species used by their households. Additionally, we used One Way ANOVA analysis to test if the number of useful plant species used is different among ethnic groups.

\section{Study Area}

Field work was conducted in Ben En National Park, situated in Nhu Thanh and Nhu Xuan districts of the Thanh Hoa province in Vietnam at $19^{\circ} 40^{\prime} \mathrm{N}$ by $105^{\circ} 21^{\prime}$ to $105^{\circ} 35^{\prime} \mathrm{E}$. (Fig. 1). Before its establishment in 1986, the park was a logging enterprise, resulting in the fact that big trees with a diameter at breast height of over one meter were rarely observed during our field work. Ben En National Park was established as a protected area in 1986 and as a national park in 1992. Since then all logging activities have been illegal. The core zone of the national park covers 15,800 ha, while the buffer zone covers around 12,000 ha. About 18,000 people live in the buffer and core zones of the national park. (Tordoff et al. 2000). The majority of the people living in the national park belong to the Kinh, Thai, Muong, and Tay ethnic groups, although there are also a small number of Tho people. All ethnic groups 


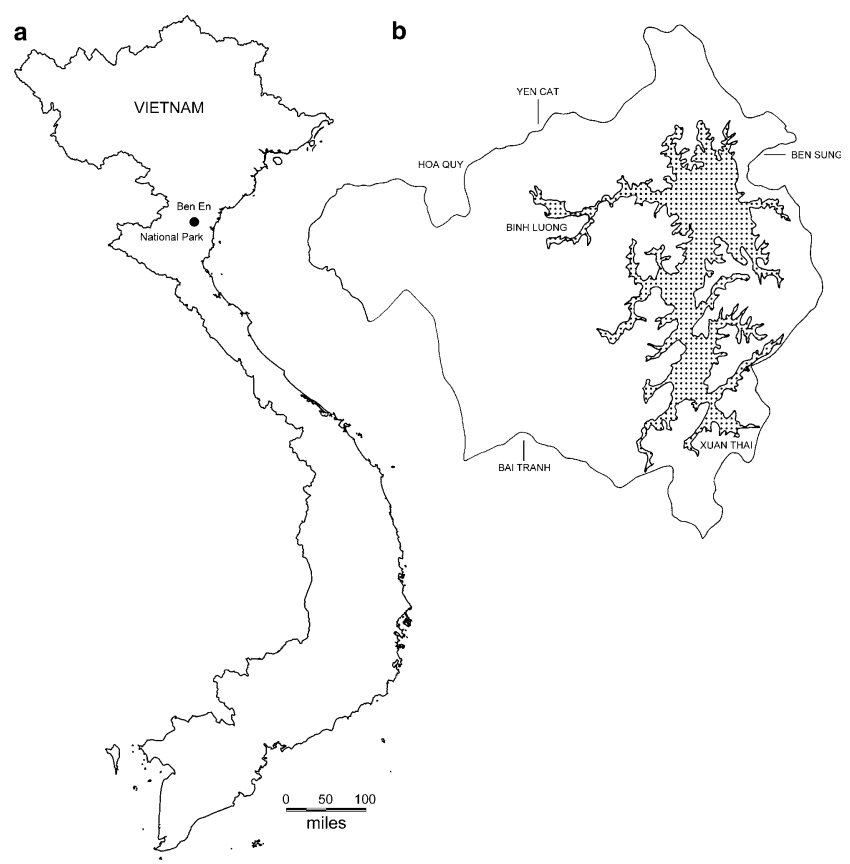

Fig. 1. a) Map of Vietnam. b) Map of Ben En National Park.

have their own languages, but all can communicate in the national King (Viet) language. Most households in the research area have their own home garden, varying in size from 100 to 2,000 sq.m, implying that $26 \%$ of the total land in the buffer zone is thus managed by local people. This includes 2,620 ha $(8.4 \%)$ of secondary forest and poor forest lands, 2,256 ha $(7.3 \%)$ of bare land or land with some small trees and shrubs, 443 ha $(1.4 \%)$, of plantation forest, and 2,554 ha $(8.2 \%)$ of agricultural land. There are plans to allocate more land to local households in the future. In some areas, land is being planted with sugar cane and cassava, and in other areas reforestation is taking place with Eucalyptus camaldulensis, (Myrtaceae), Acacia mangium, Acacia auriculiformis (Mimosaceae), Hevea brasiliensis (Euphorbiaceae), and fruit trees.

The interviews were carried out in three villages: Xuan Thai, Binh Luong, and Hoa Quy. Additional information on useful plants was collected in the Ben Sung, Yen Cat, and Xuan Thai markets and from several companies making furniture in and around the park. There are nine vegetation types in Ben En National Park (Hoang et al. 2008b); the vegetation of the core zone is dominated by tropical evergreen forest, which has been disturbed by human activities, principally by logging.

\section{Results \\ Diversity of Useful Plant Species}

A total of 208 plant species were found to be used by local people in Ben En National Park (excluding medicinal plant species, which are surveyed elsewhere, see Hoang et al. 2008a). These species belong to 130 genera and 64 families. A complete list of useful nonmedicinal plant species is given in Appendix 1.

From the 208 useful species, 59\% are collected exclusively from the wild (primary, secondary, and logged-over forest); $31 \%$ of the species are cultivated in home gardens or in fields and mostly used as vegetables or for their fruits, e.g., Mangifera indica (Anacardiaceae), Artemisia vulgaris (Asteraceae), and Diospyros kaki (Ebenaceae); another $10 \%$ of the species are taken from the forest and planted in home gardens, e.g., Garcinia cowa, Garcinia multiflora (Clusiaceae), and Dracontomelon dao (Anacardiaceae).

\section{Plant Parts Used}

In Appendix 1, the different plant parts used of each species are indicated. Stems of trees, shrubs, and lianas are most commonly used, for construction, firewood, or handicrafts. Fruits and leaves are also commonly used, mostly for food. 
Twenty-two species are used by local people as whole plants, mostly for ornamental purposes, e.g., Euphorbia pulcherrima (Euphorbiaceae), and Acanthopanax trifoliatus (Araliaceae). Some small plants are used as vegetables, such as Centella asiatica (Apiaceae). Local people use seeds, resin, branches, or bark of only a few species. For instance, seeds of Michelia tonkinensis, and Michelia mediocris (Magnoliaceae) are used as spice for food. Resin of Canarium album and Canarium tramdennum (Burseraceae) is used for making candles. Bark of Artocarpus tonkinensis (Moraceae) is chewed, together with leaves of Piper betle (Piperaceae) and fruits of Areca catechu (Arecaceae)—this is a traditional custom in Vietnam.

\section{Diversity of Commodity Groups}

Table 1 shows the distribution of useful plants in the five end-use categories. The different commodity groups are discussed below.

\section{Food}

Food (fruits and vegetables) is the most important end-use category. Sixty wild species are collected from the forest, e.g., leaves of Meliantha suavis (Opiliaceae), Maesa balansae (Myrsinaceae), Vernonia solaniflora (Asteraceae), Callipteris esculenta (Athyriaceae), Erythropalum scandens (Olacaceae), Schefflera octophylla (Araliaceae), fruits of Baccaurea ramiflora (Euphorbiaceae), and tubers of Dioscorea persimilis (Dioscoreaceae). A total of 64 wild species have already been introduced in home gardens or agricultural fields, such as Polyscias fruticosa (Araliaceae), Telosma cordatum (Asclepiadaceae), Dracontomelon dao, and Spondias lakoensis (Anacardiaceae). All households interviewed collect bamboo shoots of Schizostachyum funghomii (Poaceae) for food; $32 \%$ of the households also collect these shoots for trading, both fresh and dried in local markets,

Table 1. Commodity Groups of USEFUl PLANTS IN BEN EN NATIONAL PARK.

\begin{tabular}{lcc}
\hline \hline Commodity group & Number of plant species & Percent/total (\%) \\
\hline Food & 142 & 68 \\
Construction & 40 & 19 \\
Firewood & 25 & 12 \\
Household tools & 18 & 9 \\
$\quad$ and related products & & \\
Other & 16 & 8 \\
\hline
\end{tabular}

and sell them to traders from Yen Cat, Ben Sung, and Bai Tranh, three neighboring towns at a distance of 8-20 km from Ben En.

\section{Construction}

Although Ben En was established as a national park in 1992, illegal logging by people inside and outside the park is still taking place. A total of 40 species are used by local people for construction and furniture, e.g., Erythrophloeum fordii (Caesalpiniaceae), Paviesia annamensis (Sapindaceae), Vatica odorata (Dipterocarpaceae), Actinodaphne obovata (Lauraceae), and Dysoxylum cauliflorum (Meliaceae). Some rattan and bamboo species, such as Dendrocalamus barbatus and Bambusa blumeana (Poaceae), are used for construction of animal cages (pigs, cows, buffaloes, chickens), and some households still use leaves of the palm Livistona chinensis for thatching. The 15 most important local timber species, according to interviews with forest rangers and local people, and according to their stump frequency in the research plots (Hoang et al. 2008b; Hoang et al. in preparation), are listed in Table 2.

\section{Firewood}

All households in the research area still depend on firewood for their cooking, heating, and other energy sources. Twenty-five species were recorded for firewood use; most of them are collected from the forest, particularly forest land that belongs to the individual families. Small trees or branches are used that can easily be chopped into small pieces and quickly lit, from species such as Xylopia pierrei (Annonaceae), Cratoxylum polyanthum (Clusiaceae), Melastoma normale, or Melastoma septemnervium (Melastomataceae). Some cultivated species are also used, such as Acacia auriculaeformis, Acacia mangium (Mimosaceae), Eucalyptus camaldulensis (Myrtaceae), Pinus massoniana, and P. merkusii (Pinaceae). Local people also make charcoal by burning the stumps and branches of Erythrophloeum fordii (Caesalpiniaceae) that have already been cut for their timber.

\section{Household Tools and Related Products}

A total of 18 species are used for household tools and related products, e.g., Dendrocalamus barbatus, Bambusa blumeana, and Schizostachyum funghomii (Poaceae) to make baskets; Calamus balansaeanus, 
TAble 2. Important Timber treEs in BEN EN NATIONAL PARK AND THEIR USE INDEX (UI).

\begin{tabular}{llc}
\hline \hline Scientific Name & \multicolumn{1}{c}{ Family } & Use Index (UI) \\
\hline Actinodaphne obovata Blume & Lauraceae & 0.65 \\
Aglaia spectabilis (Miq.) S.S. Jain \& Bennet & Meliaceae & 0.56 \\
Amesiodendron chinense (Merr.) Hu & Sapindaceae & 0.56 \\
Aphanamixis grandifolia Blume & Meliaceae & 0.53 \\
Dysoxylum cauliflorum Hiern & Meliaceae & 0.78 \\
Erythrophloeum fordii Oliv. & Caesalpiniaceae & 0.99 \\
Garcinia fagraeoides A. Chev. & Clusiaceae & 0.52 \\
Lagerstoemia calyculata Kurz & Lythraceae & 0.81 \\
Michelia mediocris Dandy & Magnoliaceae & 0.84 \\
Parashorea chinensis Wang Hsie & Dipterocarpaceae & 0.81 \\
Pavieasia annamensis Pierre & Sapindaceae & 0.85 \\
Peltophorum tonkinensis Pierre & Caesalpiniaceae & 0.54 \\
Phoebe paniculata Nees & Lauraceae & 0.66 \\
Vatica harmandiana Pierre & Dipterocarpaceae & 0.54 \\
Vatica odorata (Griff.) Symingtom & Dipterocarpaceae & 0.50 \\
\hline
\end{tabular}

Calamus faberi, and Calamus tetradactylus (Arecaceae) for handicrafts, e.g., cane chairs and tables, pillows, boxes; and Baeckea frutescens for making brooms.

\section{Other Uses}

Only 11 species are used as ornamental plants in the research area, e.g., Camellia amplexicaulis (Theaceae), Acanthopanax trifoliatus (Araliaceae), Cycas revoluta (Cycadaceae), Barringtonia acutangula (Lecythidaceae), and several orchid species.

Leaves of Phrynium placentarium (Marantaceae) are used for wrapping rice cake. Twelve species are collected for paper making (e.g., Acacia auriculaeformis, Acacia mangium [Mimosaceae], and Schizostachyum funghomii [Poaceae]) and sold to a pulp mill in Lam Son, $15 \mathrm{~km}$ away from the park. Pterocarya tonkinensis (Juglandaceae) is used to stupefy fish: leaves are crushed and immersed in streams and ponds as a mild fish poison that immobilizes the fish but does not affect their edibility after the fish is caught in this way.

\section{Commercialization of Useful Plants}

A total of 38 of the 208 useful species in the park are commercialized. Most of these species are sold to traders or in the local markets. The commercial plant species are listed in Appendix 2. Of these, 14 are cultivated in home gardens, mostly as fruit trees and vegetables, e.g., Musa paradisiaca (Musaceae) Citrus maxima, Citrus sinensis (Rutaceae), Psidium guajava (Myrtaceae), Ocimum basilicum (Lamiaceae), Luffa cylindrica, and Lagenaria siceraria (Cucurbitaceae). The remaining 24 commercial species are collected from the forest for a variety of end-uses, such as resin for candle manufacturing (from Canarium album and Canarium tramdenum [Burseraceae]) or leaves and shoots as vegetables (e.g., from Meliantha suavis [Opiliaceae] and Schizostachyum funghomii [Poaceae]). Illegal logging of 15 timber species (Table 2) for domestic use and trade is still ongoing. The most important species is Erythrophloeum fordii (Caesalpiniaceae). The timber is sold to traders or furniture manufacturers. Only 24

TABle 3. AnNual income PER HOUSEHOLd IN BEN EN NATIONAL PARK.

\begin{tabular}{lccl}
\hline \hline Resource & Income in US\$ & Percentage (\%) & Remark \\
\hline Agriculture & 150 & 36 & Crops such as rice and corn \\
Livestock & 100 & 24 & Pigs, chickens, dogs, and cows \\
Nonmedicinal useful plants & 50 & 12 & See Appendix 2 \\
Medicinal plants & 45 & 11 & See Hoang et al. 2008a \\
Others & 75 & 17 & Employment, fishing, trading, etc. \\
Total & $\mathbf{4 2 0}$ & $\mathbf{1 0 0}$ & \\
\hline
\end{tabular}


Table 4. Gender and age Classes of local people HARVESTING USEFUL PLANTS IN BEN EN NATIONAL PARK.

\begin{tabular}{llc}
\hline \hline Age & Gender & $\begin{array}{c}\text { Percentage of individuals harvesting } \\
\text { useful plants (\%) }\end{array}$ \\
\hline$>50$ & Male & 15 \\
& Female & 8 \\
$26-50$ & Male & 34 \\
& Female & 23 \\
$16-25$ & Male & 8 \\
& Female & 7 \\
$<16$ & Male & 3 \\
& Female & 2 \\
Average \% of Males & 60 \\
Average \% of Females & 40 \\
\hline
\end{tabular}

families collect firewood for trade, but the income from it is low. Eight families produce charcoal for trading at a price of about USD 6/100 kg.

The income of each commercialized plant species is shown in Appendix 2. Income of local people per household in Ben En National Park is shown in Table 3.

\section{Who Is Collecting Useful Plants?}

Interviews with households and key informants revealed that men collect useful plants more often than women at almost every age level, especially in the age range from 20 to 50 (Table 4). This is in contrast to medicinal plants, which are chiefly collected by women (Hoang et al. 2008a). Moreover, activities such as cutting timber, harvesting firewood, collecting honey, and making charcoal are almost all carried out by men. Young people participate more actively in collecting nonmedicinal useful plants than medicinal ones (Hoang et al. 2008a). However, people younger than 25 years are less active in collecting both nonmedicinal useful and medicinal plants than older people, because the older people in the research area have a better knowledge of useful plants, and many young people are employed outside the park (Hoang et al. 2008a).

\section{Importance of Useful Plants FOR THE LOCAL COMMUNITIES}

Firewood is considered to be the most important useful plant by local people, irrespective of which species is used. All households in the study area use firewood as the main fuel to cook food for people and pigs (pigs are also an important source of income-see Table 3) and for heating. In fact, the prices of the alternative fuels like electricity, gas, and kerosene are too high and cannot be afforded by the local people, while firewood is freely available.

In addition to firewood, the bamboo shoots of Schizostachyum funghomii (Poaceae) are also very important because they are not only collected for local consumption, but also for generating cash. The average income from this species was US\$ 13/per year/per household in 2005. Erythrophloeum fordii (Ceasalpiniaceae) is the most important timber species, not only for timber, but also for charcoal.

The use index of species varies widely (Appendix 1), from 0.01 to 1 , indicating that some species are only used by $1 \%$ of all households (e.g., the orchid Dendrobium aloideum used by only two households for ornamental purposes), while others are used by virtually all households (e.g., onion, ginger, garlic, and sweet potato). Most species with UI higher than 0.75 are cultivated food plants, but some timber trees also have high use value, such as Erythroploeum fordii (Ceasalpiniaceae) (0.99), Pavieasia annamensis (Sapindaceae) (0.85), Michelia mediocris (Magnoniaceae) (0.84), and Parashorea chinensis (Dipterocarpaceae) (0.81). The vast majority of species are, however, used by less than half of the households, and $37 \%$ of the useful species have use indices lower than 0.25 .

\section{Conservation Status}

A total of 8 plant species used by local people from Ben En National Park are listed in the IUCN Red Data List (IUCN 2006), and 11 species are listed in the Red Data Book of Vietnam (Ban 2007) (Table 5). Based on our plot inventories (density of living trees and stumps) and interviews with forest rangers and local people, a total of 27 species appears to be endangered, vulnerable, rare, or threatened in the park (Table 5). For instance, Cycas revoluta, and Cycas chevalieri (Cycadaceae) are rare in Ben En, and local people also collect these species for ornamental purposes, although the pressure of collecting is low and the market demand is not high. All the used timber tree species are illegally exploited by local people in Ben En, and trespassers are often caught by the forest ranger of the park. Actinodaphne obovata, Phoebe paniculata (Lauraceae), and Erythrophloeum fordii (Caesalpiniaceae) are not difficult to find in the 
TABle 5. Useful Plants in BEN EN NATIONAL PARK Listed IN THE IUCN RED LiST OF THREATENED SPECiES (2006), THE RED DATA BOOK OF VIETNAM (BAN 2007), AND CONSIDERED AS THREATENED SPECIES IN BEN EN NATIONAL PARK ON THE BASIS OF THIS STUDY.

\begin{tabular}{|c|c|c|c|c|}
\hline Species & Family & $\begin{array}{c}\text { Threat category } \\
\text { in Red Data } \\
\text { Book of Vietnam }\end{array}$ & $\begin{array}{l}\text { Threat category } \\
\text { in IUCN } \\
\text { Red List } 2006\end{array}$ & $\begin{array}{c}\text { Threat category } \\
\text { in Ben } \\
\text { En (this study) }\end{array}$ \\
\hline Actinodaphne obovata Blume & Lauraceae & $\mathrm{nl}$ & $\mathrm{nl}$ & $\mathrm{t}$ \\
\hline Aglaia spectabilis (Miq.) S.S. Jain \& Bennet & Meliaceae & $\mathrm{vu}$ & $\mathrm{nl}$ & $\mathrm{t}$ \\
\hline Alstonia scholaris (L.) R. Br. & Apocynaceae & $\mathrm{nl}$ & $\operatorname{lr}$ & $\mathrm{nl}$ \\
\hline Amesiodendron chinense (Merr.) $\mathrm{Hu}$ & Sapindaceae & $\mathrm{nl}$ & $\operatorname{lr}$ & $\mathrm{t}$ \\
\hline Aphanamixis grandifolia Blume & Meliaceae & $\mathrm{nl}$ & $\mathrm{nl}$ & $\mathrm{t}$ \\
\hline Caesalpinia sappan L. & Caesalpiniaceae & $\mathrm{nl}$ & $\mathrm{nl}$ & $\mathrm{r}$ \\
\hline Calamus platyacanthus Warb. ex Becc & Arecaceae & vu & $\mathrm{nl}$ & $\mathrm{r}$ \\
\hline Calamus tetradactylus Hance & Arecaceae & $\mathrm{nl}$ & $\mathrm{nl}$ & $\mathrm{r}$ \\
\hline Canarium tramdenum Dai et Yakovl & Burseraceae & $\mathrm{vu}$ & $\mathrm{nl}$ & $\mathrm{r}$ \\
\hline Chukrasia tabularis A. Juss. & Meliaceae & $\mathrm{vu}$ & $\operatorname{lr}$ & $\mathrm{nl}$ \\
\hline Cycas chevalieri Leandri & Cycadaceae & $\operatorname{lr}$ & $\mathrm{cr}$ & $\mathrm{r}$ \\
\hline Cycas revoluta Thunb. & Cycadaceae & $\mathrm{nl}$ & $\mathrm{nl}$ & $\mathrm{r}$ \\
\hline Dysoxylum cauliflorum Hiern & Meliaceae & vu & $\mathrm{nl}$ & $\mathrm{t}$ \\
\hline Erythroploeum fordii Oliv. & Caesalpiniaceae & $\mathrm{nl}$ & $\mathrm{e}$ & $\mathrm{t}$ \\
\hline Garcinia fagraeoides A. Chev. & Clusiaceae & $\mathrm{vu}$ & $\mathrm{nl}$ & e \\
\hline Hopea odorata Roxb. & Dipterocarpaceae & $\mathrm{nl}$ & $\mathrm{nl}$ & $\mathrm{r}$ \\
\hline Hopea chinensis (Merr.) Hand.-Mazz. & Dipterocarpaceae & $\mathrm{nl}$ & $\mathrm{cr}$ & $\mathrm{r}$ \\
\hline Lagerstroemia calyculata Kurz & Lythraceae & $\mathrm{nl}$ & $\mathrm{nl}$ & $\mathrm{r}$ \\
\hline Manglietia fordiana Oliv. & Magnoniaceae & vu & $\mathrm{nl}$ & $\mathrm{r}$ \\
\hline Markhamia stipulata (Wall.) Soem. ex Schum. & Bignoniaceae & vu & $\mathrm{nl}$ & e \\
\hline Meliantha suavis Pierre & Opiliaceae & $\mathrm{vu}$ & $\mathrm{nl}$ & $\mathrm{r}$ \\
\hline Michelia mediocris Dandy & Magnoliaceae & $\mathrm{nl}$ & $\mathrm{nl}$ & $\mathrm{r}$ \\
\hline Parashorea chinensis (Wang Hsie) H. Zhu & Dipterocarpaceae & $\mathrm{nl}$ & e & $\mathrm{t}$ \\
\hline Pavieasia anamensis Pierre & Sapindaceae & $\mathrm{nl}$ & $\mathrm{nl}$ & $\mathrm{t}$ \\
\hline Peltophorum tonkinensis Pierre & Caesalpiniaceae & $\mathrm{nl}$ & $\mathrm{nl}$ & vu \\
\hline Phoebe paniculata Nees & Lauraceae & $\mathrm{nl}$ & $\mathrm{nl}$ & $\mathrm{t}$ \\
\hline Vatica odorata (Griff.) Symingtom & Dipterocarpaceae & $\mathrm{nl}$ & $\mathrm{nl}$ & $\mathrm{r}$ \\
\hline Vatica harmandiana Pierre & Dipterocarpaceae & $\mathrm{nl}$ & $\mathrm{e}$ & $\mathrm{r}$ \\
\hline Vatica subglabra Merr. & Dipterocarpaceae & en & $\mathrm{nl}$ & e \\
\hline
\end{tabular}

Key: en, $\mathrm{e}=$ endangered; $\mathrm{vu}=$ vulnerable; $\mathrm{r}=$ rare; $\mathrm{t}=$ threatened; $\mathrm{k}=$ insufficiently known; $\mathrm{lr}=$ least concern; $\mathrm{cr}=$ critically endangered; $\mathrm{nl}=$ not listed.

forest, but the intensity of harvesting these species by local people is high, and recent stumps were often seen during the field inventory. Additional species that are often confiscated by the forest ranger are Garcinia fagraeoides (Clusiaceae) and Markhamia stipulata (Bignoniaceae). These species are in high demand but rare in the forest, and thus locally endangered.

\section{Impact of Local People on Useful Plants in Ben En National Park}

Of all useful species in the park, 54 were recorded in the plot inventories (see Appendix 1). These species were further analyzed for impact of local use on their occurrence and density in the plots (Hoang et al. in preparation). Most of these species are used for construction and firewood. Useful plants in general and important timber trees in particular are more abundant in remote (and less disturbed) plots than close to the villages (data not shown). Not surprisingly, the density of useful plant species, especially of important timber trees, is negatively correlated with the number of stumps found in each plot (Figs. 2 and 3).

Relation of Use Index, Tree Density, and Number of People in Each Household

There is a strong correlation between number of people in each household and number of useful plant species used by each household in the 


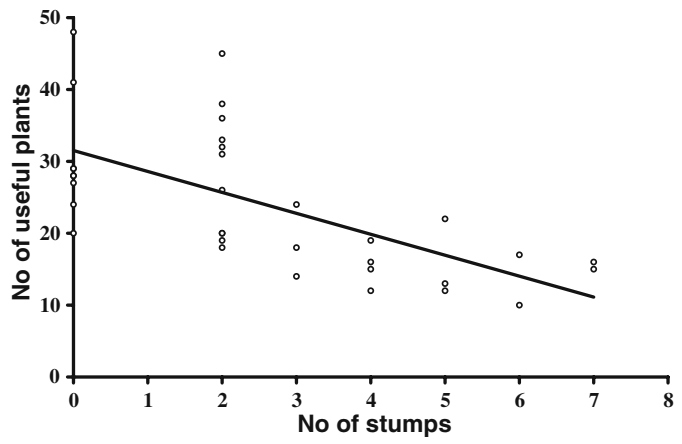

Fig. 2. Relation between the number of useful plants and number of stumps per 0.04 ha plot; $y=30.72-2.84$ $\mathrm{x} ; \mathrm{R}^{2}=0.45$.

park (Fig. 4). There are also weak but significant correlations between use index and the density of useful plants (Fig. 5).

\section{Discussion}

\section{Conservation of Useful Plant Species in Ben En National Park}

Local people, living in and around the park, still depend on natural resources. Dependence on these resources is highest in those communities living inside the core zone of the national park. The remoteness of these communities makes it difficult for people to bring building materials or other plant commodities from outside the park to their village. As a result, 27 useful plant species in Ben En National Park appear in danger of being lost locally; 16 of these are not recorded in the Red Book of Vietnam (Ban 2007). They are perhaps not only threatened in Ben En, but also in other parts of Vietnam, because the information on endangered

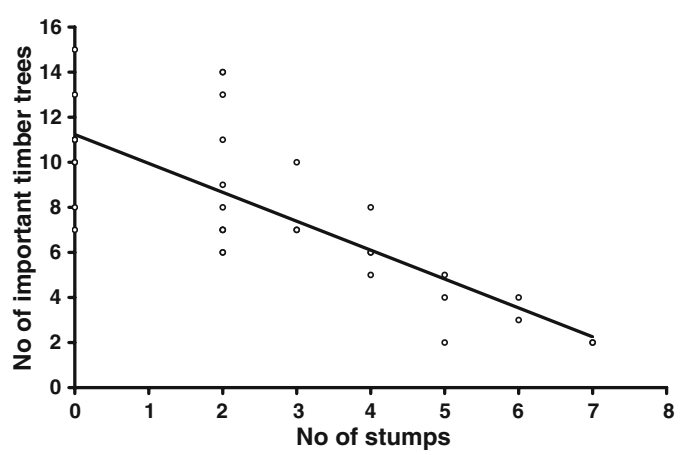

Fig. 3. Relation between the number of important timber trees and number of stumps per 0.04ha plot: $y=11.34-1.29 x ; R^{2}=0.60$.

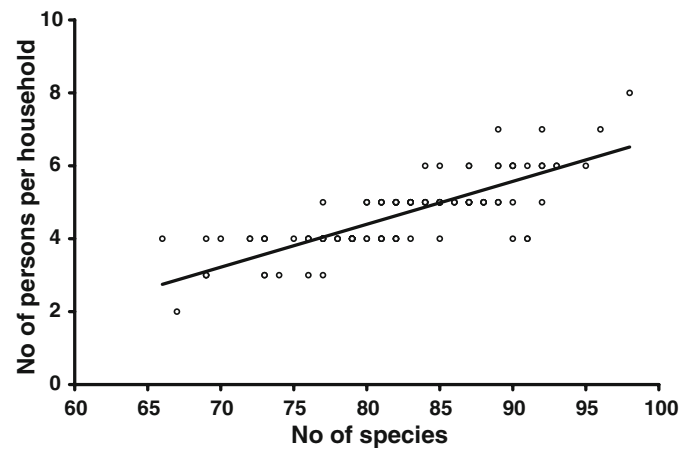

Fig. 4. Relation between number of persons in each household and number of useful plant species used. $y=0.12 x-5.02 ; R^{2}=0.64$.

species was - and still is - very incomplete. Chukrasia tabularis is listed both in the 2006 Red List of IUCN and the Red Book of Vietnam (Ban 2007); this species is endangered in nature, and it is rare in the natural forest. However, Chukrasia tabularis is planted widely in plantation forests in Vietnam, especially in and around Ben En National Park. Therefore, we did not list this species in the list of threatened species in Ben En. Another species, Alstonia scholaris (Apocynaceae), listed by IUCN (2006), is very common in plantations throughout the whole country. In contrast, Garcinia fagraeoides (Clusiaceae) is not on the IUCN list, but locally this species is endangered because of the high intensity of illegal logging and its rarity in the field inventories. Markhamia stipulata (Bignoniaceae) was an important timber tree for local people 5-10 years ago. However, this species has become endangered in Ben En: only a single tree with a diameter over $5 \mathrm{~cm}$ was found during the field inventory.

Recently illegal logging has decreased because of the strict protection by forest rangers (Hien 2006,

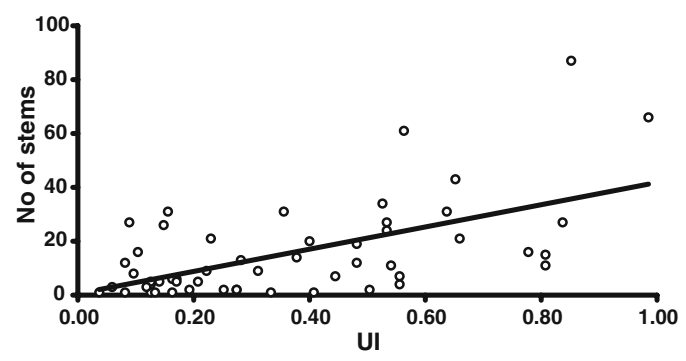

Fig. 5. Relation between number of stems per 0.04 ha plot and Use Index (UI) of 54 useful plant species. $\mathrm{y}=42.22 \mathrm{x}+0.56 ; \mathrm{R}^{2}=0.34$. 
2007). Local people also obtain land to plant trees. However, some illegal logging is still carried out in the Dong Tho, Song Chang, Duc Luong, and Bai Tranh areas. In order to reduce the impact of local people on forest resources and to improve their living conditions, the Vietnamese Government issued Decree 02/CP in 1994, making it possible to allocate forest land to individual households for protection and re-plantation, and that policy still applies in the whole country. In some buffer zones of national parks, land is being planted with sugar cane and cassava; in others reforestation is taking place with Eucalyptus camaldulensis, Acacia mangium, Acacia auriculiformis, and various fruit trees. This could reduce the pressure from local people on the park in general and in the core zone in particular. Additionally, local people should be encouraged to cultivate plant species in home gardens, using modern techniques that would increase the yield of commonly used and commercialized species.

\section{Impact of Local People on Useful Plants}

Our analysis of the occurrence and densities of useful plants in the plots (only 54 species out of the 208) has shown a significant and negative impact of harvesting and illegal logging near villages. It must be feared that-without appropriate measures-plant resources will in the future also become depleted in more remote areas. A more detailed assessment of the impact of local people on plant species diversity and species densities throughout the park is currently in preparation (Hoang et al. in preparation).

\section{Some Factors Affecting Plant Use}

We found no differences among ethnic groups regarding plant use (data not shown), but instead a significant relationship between the size of households and the number of species used per household. According to Philips and Gentry (1993), Johns et al. (1990), and De Lucena et al. (2007), traditional plant use is strongly influenced by factors such as abundance in the forest and plant size and conspicuousness of individual species. Our analysis of the Use Index (UI) and other indicators of plant uses such as species ranking by informants and commercial value to some extent confirm this: in the plots, species with a high UI are indeed more common than species with a low UI (Fig. 5), and all very useful commercial timber trees (both by species ranking and high UI, Table 2) are indeed big and conspicuous. There are, however, major exceptions to these trends: several important timber tree species with high UI are of very infrequent occurrence in all plots, e.g., Vatica odorata (UI= 0.50), Parashorea chinensis (0.81) Amesiodendron chinense (0.56), and Garcinia fagraeoides (0.52) (Hoang et al. in preparation). Also, several species with very high UI are inconspicuous, small plants in the forest, e.g., Artemisia vulgaris (0.52), Hydrocotyle sibthorpioides (0.67), Baubinia coccinea (0.69), and Perilla frutescens (0.57) (cf. Appendix 1). For many cultivated plant species, there is an interesting discrepancy between the calculated UI and the relatively low ranking given in the PRA questionnaires (results not shown), suggesting that local people take many cultivated species "for granted" in their response to our interviews using PRA techniques.

The Use Index spectrum for nonmedicinal useful plants is quite different from that of medicinal plants (Hoang et al. 2008a): for medicinal plant species, the vast majority $(68 \%)$ have low UI values $(<0.25)$, and only $8 \%$ have high values > 0.75 (for the nonmedicinal plants these values are $32 \%$ and $16 \%$, respectively). This indicates that traditional medicinal use of wild plant species is less common than the use of nonmedicinal plants, perhaps because in many households the knowledge of or confidence in the therapeutic efficacy of a certain species is low, while nonmedicinal uses are much more straightforward.

\section{Valuation of Traditional Plant Use}

The contribution to income generation of nonmedicinal and medicinal plants collected in the wild or grown in home gardens was calculated to amount to $23 \%$ or USD 95 per household per annum (Table 3). These figures are only rough approximations since they are based on interviews with local people and on market inventories, each with their own sources of error and imprecision. Nevertheless, the total economic value of traditional plant use far exceeds this monetary component for the people of Ben En National Park, since it offers important commodities such as vegetables, fruits, condiments, fuel, construction materials, medicines, etc., "free of monetary charge," but in return for fairly light collecting and plant cultivation efforts. It would be interesting to calculate the monetary equivalents for all these free commodities, but our data unfortunately do not allow this. Conversely, the costs of overexploitation and 
ecological degradation should also be modeledan even more difficult exercise, beyond the scope of this study.

\section{Acknowledgments}

The authors are grateful to the Vietnamese government for financial support of Hoang Van Sam to carry out the project at Leiden University. We are also grateful to the International Foundation of Science (IFS) for financial support to do the fieldwork in Ben En National Park. We would like to thank Professor Dr. Jan Slikverveer for his useful comments. Dr. F. A. C. B. Adema, Dr. M. M. J. van Balgooy, Dr. Ding Hou, Dr. H. P. Noteboom, Dr. P. C. van Welzen, and Dr. W. J. J. O. de Wilde (National Herbarium of the Netherlands, Leiden University branch), and Nguyen Van Huy, Nguyen Van Nghia, Le Mong Chan (Vietnam Forestry University), kindly helped us to identify the numerous plant species. We also would like to thank Hoang Van Cuong, $\mathrm{Vu}$ Van Dinh, Pham Thanh Trang, and Nguyen Tuan Phuong, students at the Vietnam Forestry University, for their assitance in the field. In addition, we thank the staff and local people in Ben En National Park for their support of our activities, especially Nguyen Danh Hien, Luong Xuan Ha, Dang Huu Nghi, Pham Hong Phong, and Le Dinh Phuong.

\section{Open Access}

This article is distributed under the terms of the Creative Commons Attribution Noncommercial License which permits any noncommercial use, distribution, and reproduction in any medium, provided the original author(s) and source are credited.

\section{Literature Cited}

Amacher, G. S. 2002. Forest Policies and Many Governments. Forest Science 48 (1):146-158.

Anonymous. 2000. The List of Plants and Animals in Ben En National Park. Report from Sub Institute of Forest Inventory and Planning II. Nghe An, Vietnam (in Vietnamese).

Ban, N. T., ed. 2007. Red Data Book of Vietnam. Vol. 2. Science and Techniques Publishing House, Hanoi, Vietnam (in Vietnamese).
Clay, J. W. 1997. The Impact of Palm Heart Harvesting in the Amazon Estuary. Pages 283-314 in C. H. Freese, ed., Harvesting Wild Species: Implications for Biodiversity Conservation. Johns Hopkins University Press, Baltimore, Maryland.

Cunningham, A. B. 2001. Applied Ethnobotany: People, Wild Plant Use and Conservation. People and plants conversation manual. Earthscan, London.

De Lucena, R. F. P., E. de Lima Araujo, and U. P. de Albuquerque. 2007. Does the Local Availability of Woody Caatinga Plants (Northeastern Brazil) Explain Their Use Value? Economic Botany 61:347-361.

Hien, D. N. 2006. Report of Ben En National Park in 2006 (in Vietnamese).

- 2007. Report of Ben En National Park in 2007 (in Vietnamese).

Ho, P. H. 2000. An Illustrated Flora of Vietnam. Youth Publishing House, Ho Chi Minh City, Vietnam (in Vietnamese).

Hoang, S. V., P. Baas, and P. J. A. Keßler. (2008a). Traditional Medicinal Plants in Ben En National Park, Vietnam. Blumea 53(3).

—, and $\longrightarrow$. (2008b). Plant Biodiversity in Ben En National Park, Vietnam (in press).

Hung, T. V., ed. 2007. Non Timber Forest Products in Vietnam. Agricultural Publishing House, Vietnam (in Vietnamese).

IUCN. 2006. The IUCN Red List of Threatened Species. http://www.redlist.org/info/tables/table6a.

Johns, T., J. O. Kakwaro, and E. K. Kimanani. 1990. Herbal Remedies of the Luo of Siaya District, Kenya: Establishing Quantitative Criteria for Consensus. Economic Botany 44:369-381.

Lange, D. 1998. Europe's Medicinal and Aromatic Plants: Their Use, Trade and Conservation. TRAFFIC International, Cambridge, U.K.

Martin, G. J. 1995. Ethnobotany: A Methods Manuals. Cambridge University Press, Cambridge, U.K.

Nepstad, D. C. and S. Schwartzman. 1992. NonTimber Product Extraction from Tropical Forest: Evaluation of a Conservation and Development Strategy. New York Botanical Garden, Bronx, New York.

Ngai, N. B. 2001. Methodology of Rural Appraisal. Vietnam Forestry University, Vietnam (in Vietnamese). 
Panayotou, T. and P. S. Ashton. 1992. Not by Timber Alone: The Case for Multiple Use Management of Tropical Forests. Island Press, Covelo, California.

Phillips, O. and A. H. Gentry 1993. The Useful Plants of Tambopata, Peru: Statistical Hypotheses Tests with a New Quantitative Technique. Economic Botany 47:15-32.

PID and NES. 1989. An Introduction to Participation, Rural Appraisal for Rural Resources Management, Program for International Development, Clark University, Worcester, Massachusetts, and National Environment Secretariat, Ministry of Environment and Natural Resources, Nairobi.
Prance, G. T., W. Balee, B. M. Boom, and R. L. Carneiro 1987. Quantitative Ethnobotany and the Case for Conservation in Amazonia. Conservation Biology 1:296-310.

PROSEA. 1989-2003. Plant Resources of SouthEast-Asia. Handbooks No. 1-19 (multiple editors and authors). Pudoc, Wagenigen (No. 1-6), and Backhuys Publishers, Leiden (No. 7-19), the Netherlands.

Tiwari, B. K. 2000. Non-Timber Forest Products of Northeast India. Journal of Human Ecology 11:445-455.

Tordoff, A., E. Fanning, and M. Grindley, eds. 2000. Ben En National Park. Society for Environmental Exploration, London. 
Appendix 1. Plant species used by local people in BEn en national Park.

\begin{tabular}{|c|c|c|c|c|c|}
\hline Scientific name & Common name $\mathbf{U}$ & se inde & //Culti & Part utilized & Use \\
\hline Ferns & & & & & \\
\hline Gleicheniaceae & Họ Guột & & & & \\
\hline Dicranopteris linearis (Burm.) Underw. & Guột & 0.28 & W & Whole plant & Firewood \\
\hline Marsileaceae & Họ Rau Bọ’ & & & & \\
\hline Marsilea quadrifolia L.* & Rau bợ & 0.14 & W & Leaves & Food \\
\hline Woodsiaceae & Ráng gố nhỏ & & & & \\
\hline Diplazium esculentum (Retz.) Sw. & Rau rớn & 0.30 & $\mathrm{~W}$ & Leaves & Food \\
\hline Gymnosperms & Ngành Thông & & & & \\
\hline Cycadaceae & Họ Tuế & & & & \\
\hline Cycas chevalieri Leandri & Nghèn & 0.12 & $\mathrm{~W}$ & Whole plant & Ornamental \\
\hline Cycas revoluta Thunb. & Vạn tuế & 0.08 & $\mathrm{~W}$ & Whole plant & Ornamental \\
\hline Gnetaceae & Họ Dây gắm & & & & \\
\hline Gnetum gnemon L. & Gắm & 0.29 & $\mathrm{~W}$ & Fruit & Food \\
\hline Pinaceae & Họ Thông & & & & \\
\hline Pinus massoniana D. Don & Thông đuôi ngựa & 0.33 & $\mathrm{~W}, \mathrm{C}$ & Branch, stem & $\begin{array}{l}\text { Construction, } \\
\text { firewood }\end{array}$ \\
\hline Pinus merkusii Jungh. \& de Vriese & Thông nhựa & 0.36 & W,C & Branch, stem & Construction, \\
\hline Angiosperms & Ngành Ngọc Lan & & & & firewood \\
\hline Dicotyledons & Lop Ngọc Lan & & & & \\
\hline Amaranthaceae & Họ Rau Dền & & & & \\
\hline Alternanthera sessilis (L.) A. DC. & Rau diếp dại & 0.24 & $\mathrm{~W}$ & Leaves & Food \\
\hline Amaranthus spinosus L. & Dền cơm & 0.26 & $\mathrm{C}$ & Leaves & Food \\
\hline Amaranthus tricolor $\mathrm{L}$. & Dền tía & 0.08 & $\mathrm{C}$ & Leaves & Food \\
\hline Anacardiaceae & Họ Xoài & & & & \\
\hline $\begin{array}{l}\text { Dracontomelon dao (Blanco) Merr. \& } \\
\text { Rolfe }\end{array}$ & Sấu & 0.19 & W,C & $\begin{array}{l}\text { Fruit, leaves, } \\
\text { stem }\end{array}$ & $\begin{array}{l}\text { Food, } \\
\text { construction }\end{array}$ \\
\hline Mangifera indica $\mathrm{L}$. & Xoài & 0.43 & $\mathrm{C}$ & Fruit & Food \\
\hline Mangifera reba Pierre & Quéo & 0.06 & $\mathrm{~W}, \mathrm{C}$ & Fruit & Food \\
\hline Spondias axillaris Roxb. & Xoan nhừ & 0.08 & W & Fruit & Food \\
\hline Spondias lakoensis Pierre * + & Dâu da xoan & 0.25 & W,C & Fruit & Food \\
\hline Annonaceae & Họ Na & & & & \\
\hline Annona squamosa L. * & $\mathrm{Na}$ & 0.16 & $\mathrm{C}$ & Fruit & Food \\
\hline Xylopia vielana Hance $*+$ & Dền & 0.91 & $\mathrm{~W}$ & Stem & Firewood \\
\hline Apiaceae & Họ Hoa Tán & & & & \\
\hline Anethum graveolens $\mathrm{L}$. & Thì là & 0.27 & $\mathrm{C}$ & Leaves, stem & Food \\
\hline Centella asiatica (L.) Urb. * & Rau má & 0.30 & W & Whole plant & Food \\
\hline Coriandrum sativum $\mathrm{L}$. & Rau mùi & 0.32 & $\mathrm{C}$ & Leaves, stem & Food \\
\hline Eryngium foetidum Thunb. & Mùi tàu & 0.31 & $\mathrm{C}$ & Leaves, stem & Food \\
\hline Hydrocotyle sibthorpioides Lamk. & Rau má & 0.67 & $\mathrm{~W}$ & Whole plant & Food \\
\hline Apocynaceae & Họ Trúc Đào & & & & \\
\hline Alstonia scholaris (L.) R. Br. * & Sữa & 0.04 & $\mathrm{~W}$ & Whole plant & Ornamental \\
\hline Holarrhena antidysentirica Wall. & Mộc hoa trắng & 0.04 & $\mathrm{~W}$ & Whole plant & Ornamental \\
\hline Aquifoliaceae & Họ Nhựa ruồi & & & & \\
\hline Ilex macrocarpa Oliv. & Bùi quả to & 0.07 & W & Leaves & Drink \\
\hline Ilex rotunda Thunb. + & Nhựa ruồi & 0.08 & W & Leaves & Drink \\
\hline Araliaceae & Họ Ngũ ra bì & & & & \\
\hline Acanthopanax aculeatum Seem. & Ngũ ra bì & 0.07 & $\mathrm{~W}$ & Whole plant & Ornamental \\
\hline Polyscias fruticosa Harms & Đinh lăng & 0.42 & $\mathrm{C}$ & Leaves & Food \\
\hline Schefflera alpina Grushv. \& Skvorts. & Chân chim & 0.30 & $\mathrm{~W}$ & Leaves & Food \\
\hline Schefflera octophylla Harms *+ & Chân chim 8 lá & 0.48 & W & Leaves & Food \\
\hline Asclepiadaceae & Họ Thiên lý & & & & \\
\hline Telosma cordata Merr.* & Thiên lý & 0.26 & $\mathrm{C}$ & Flower & Food \\
\hline Asteraceae & Họ Cúc & & & & \\
\hline Artemisia vulgaris L. * & Ngãi cứu & 0.52 & $\mathrm{C}$ & Leaves & Food \\
\hline
\end{tabular}




\begin{tabular}{|c|c|c|c|c|c|}
\hline Scientific name & Common name & Jse index & x Wild/Cultivated & Part utilized & Use \\
\hline Artemisia japonica Thunb. & Ngãi cứu rừng & 0.16 & $\mathrm{~W}$ & Leaves & Food \\
\hline Gynura crepidioides Benth* & Rau tàu bay & 0.21 & $\mathrm{~W}$ & Leaves & Food \\
\hline Lactuca indica $\mathrm{L}$. & Bồ công anh & 0.36 & $\mathrm{~W}$ & Leaves & Food \\
\hline Vernonia andersonii C. B. Clarke & Dây rau ráu & 0.22 & $\mathrm{~W}$ & Leaves & Food \\
\hline Basellaceae & Họ Mồng tơi & & & & \\
\hline Basella alba $\mathrm{L}$. & Mồng tơi & 0.70 & $\mathrm{C}$ & Leaves & Food \\
\hline Bignoniaceae & Họ Đinh & & & & \\
\hline Markhamia stipulata Seem ex Schum.+ & Đinh & 0.41 & $\mathrm{~W}$ & Stem & Construction \\
\hline Oroxylum indicum (L.) Benth. ex Kurz* + & Núc nác & 0.13 & $\mathrm{~W}$ & Fruit & Food \\
\hline Brassicaceae & Họ Cải & & & & \\
\hline Brassica chinensis L. & Cải bẹ trắng & 0.91 & $\mathrm{C}$ & Leaves & Food \\
\hline Brassica integrifolia West. & Cải ngot & 0.73 & $\mathrm{C}$ & Leaves & Food \\
\hline Brassica juncea (L.) Czern. & Cải canh & 0.74 & $\mathrm{C}$ & Leaves & Food \\
\hline Raphanus sativus L. & Cải củ & 0.70 & $\mathrm{C}$ & Leaves, tuber & Food \\
\hline Burseraceae & Họ Trám & & $\mathrm{W}$ & Resin, fruit & Candles, food \\
\hline Canarium album Rauesch.+ & Trám trắng & 0.53 & $\mathrm{~W}$ & Resin, fruit & Candles, food \\
\hline Canarium tonkinensis L.+ & Trám chim & 0.27 & $\mathrm{~W}$ & Resin & Candles \\
\hline Canarium tramdenum Dai \& Yakovl.+ & Trám đen & 0.53 & & & \\
\hline Caesalpiniaceae & Họ Vang & & $\mathrm{W}, \mathrm{C}$ & Whole plant & Ornamental \\
\hline Bauhinia variegata $\mathrm{L}$. & Ban & 0.04 & $\mathrm{~W}$ & Stem & Drink \\
\hline Bauhinia coccinea DC & Quạch & 0.69 & $\mathrm{~W}$ & Stem, branch & Drink \\
\hline Caesalpinia sappan L. * & Vang & 0.07 & $\mathrm{~W}$ & Fruit & Shampoo \\
\hline $\begin{array}{l}\text { Gleditsia australis Hemsl. ex Forb. \& } \\
\text { Hemsl.+ }\end{array}$ & Bồ kết & 0.25 & & & \\
\hline Erythroploeum fordii Oliv.+ & Lim xanh & 0.99 & $\mathrm{~W}$ & Stem & Construction \\
\hline Peltophorum tonkinensis Pierre+ & Lim xẹt & 0.54 & $\mathrm{~W}$ & Stem & Construction \\
\hline Tamarindus indica $\mathrm{L}$. & $\mathrm{Me}$ & 0.20 & $\mathrm{~W}$ & Fruit & Food \\
\hline Caricaceae & Họ Đu đủ & & & & \\
\hline Carica papaya L. * & Đu đủ & 0.40 & $\mathrm{C}$ & Fruit & Food \\
\hline Clusiaceae & Họ Măng cụt & & & & \\
\hline Cratoxylum polyanthum Korth. * & Thành ngạnh & 0.18 & $\mathrm{~W}$ & Whole plant & Firewood \\
\hline Garcinia fagraeoides A. Chev.+ & Trai lý & 0.52 & $\mathrm{~W}$ & Stem & Construction \\
\hline Garcinia cowa Roxb. & Tai chua & 0.16 & $\mathrm{~W}, \mathrm{C}$ & Fruit, leaves & Food \\
\hline Garcinia multiflora Champ. ex Benth. & Dọc & 0.22 & W,C & Fruit, leaves & Food \\
\hline $\begin{array}{l}\text { Garcinia oblongifolia Champ. ex } \\
\text { Benth.*+ }\end{array}$ & Bứa & 0.23 & $\mathrm{~W}$ & Fruit, leaves & Food \\
\hline Convolvulaceae & Họ Bìm bịp & & & & \\
\hline Ipomoea batalas (L.) Lam & Khoai lang & 0.99 & $\mathrm{C}$ & Tuber, leaves & Food \\
\hline Ipomoea aquatica Foir. & Rau muống & 0.99 & $\mathrm{C}$ & Leaves, stem & Food \\
\hline Cucurbitaceae & Họ Bầu bí & & & & \\
\hline Benincasa hispida (Thunb.) Cogn. & Bí xanh & 0.27 & $\mathrm{C}$ & Fruit & Food \\
\hline Cucurbita maxima Lam* & Bí đỏ & 0.30 & $\mathrm{C}$ & Fruit & Food \\
\hline Lagenaria siceraria (Molina) Staney & Bầu & 0.26 & $\mathrm{C}$ & Fruit, leaves & Food \\
\hline Luffa a gyptiaca M. Roem. & Mướp & 0.88 & $\mathrm{C}$ & Fruit & Food \\
\hline Momordica charantia $\mathrm{L}$. & Mướp đắng & 0.20 & $\mathrm{C}$ & Fruit & Food \\
\hline $\begin{array}{l}\text { Momordica cochinchinensis (Lour.) } \\
\text { Spreng * }\end{array}$ & Gấc & 0.42 & $\mathrm{C}$ & Fruit & Food \\
\hline Dilleniaceae & Họ Sổ & & & & \\
\hline Dillenia heterosepala Finet \& Gagnep. & Lọng bàng & 0.10 & $\mathrm{~W}$ & Fruit, stem & Food, firewood \\
\hline Dillenia indica L.+ & Sồ & 0.10 & $\mathrm{~W}$ & Fruit, stem & Food, firewood \\
\hline Dipterocarpaceae & Họ Dầu & & & & \\
\hline Hopea odorata Roxb. & Sao đen & 0.56 & $\mathrm{~W}$ & Stem & Construction \\
\hline Hopea chinensis (Merr. ) Hand.-Mazz.+ & Sao & 0.39 & $\mathrm{~W}$ & Stem & Construction \\
\hline Parashorea chinensis Wang Hsie + & Chò chỉ & 0.81 & $\mathrm{~W}$ & Stem & Construction \\
\hline Vatica harmandiana Pierre+ & Táu nước & 0.54 & $\mathrm{~W}$ & Stem & Construction \\
\hline Vatica odorata (Griff.) Symington+ & Táu mật & 0.50 & $\mathrm{~W}$ & Stem & Construction \\
\hline
\end{tabular}




\begin{tabular}{|c|c|c|c|c|c|}
\hline \multirow{3}{*}{$\begin{array}{l}\text { Scientific name } \\
\text { Vatica subglabra Merr. } \\
\text { Ebenaceae }\end{array}$} & \multicolumn{5}{|c|}{ Common name Use index Wild/Cultivated Part utilized Use } \\
\hline & Táu xanh & 0.20 & $\mathrm{~W}$ & Stem & Construction \\
\hline & Họ Thị & & & & \\
\hline Diospyros decandra Lour. * & Thị & 0.42 & $\mathrm{C}$ & Fruit & Food \\
\hline Diospyros kaki L.f. & Hồng & 0.33 & $\mathrm{C}$ & Fruit & Food \\
\hline Elaeagnaceae & Họ Nhót & & & & \\
\hline Elaeagnus bonii Lecomte * & Nhót & 0.18 & $\mathrm{~W}$ & Fruit & Food \\
\hline Elaeagnus tonkinensis Serv. & Nhót nhà & 0.33 & $\mathrm{C}$ & Fruit & Food \\
\hline Euphorbiaceae & Họ Thầu Dầu & & & & \\
\hline Baccaurea ramiflora Lour. *+ & Dâu da đất & 0.44 & $\mathrm{~W}$ & Fruit & Food \\
\hline Bischofia javanica Blume *+ & Nhội & 0.21 & $\mathrm{~W}$ & Leaves & Food \\
\hline Breynia fleuryi Beille * & Bồ cu vẽ & 0.05 & W & Leaves & Food \\
\hline $\begin{array}{l}\text { Euphorbia pulcherrima Willd. ex } \\
\text { Klotzsch }\end{array}$ & Trạng nguyên & 0.06 & W,C & Whole plant & Ornamental \\
\hline Euphorbia hirta L. * & Cỏ sữa & 0.10 & $\mathrm{~W}$ & Whole plant & Drink \\
\hline Macaranga denticulata Mull. Arg.+ & Lá nến & 0.10 & $\mathrm{~W}$ & Stem & Firewood \\
\hline Mallotus paniculatus (Lam) Mull. Arg.+ & Ba soi & 0.38 & $\mathrm{~W}$ & Stem & Firewood \\
\hline Manihot esculenta Crantz & Sắn & 0.80 & $\mathrm{C}$ & Tuber & Food \\
\hline Phyllanthus emblica $\mathrm{L}$. & Me rừng & 0.19 & $\mathrm{~W}$ & Fruit & Food \\
\hline Sauropus androgynus Merr. & Rau ngót & 0.39 & $\mathrm{C}$ & Stem & Food \\
\hline Vernicia montana Lour.+ & Trẩu & 0.17 & W,C & Fruit & Oil, firewood \\
\hline Fabaceae & Họ Đậu & & & & \\
\hline Lablab purpureus (L.) Sweet & Đậu ván & 0.29 & $\mathrm{C}$ & Fruit & Food \\
\hline Pachyrhizus erosus (Lour.) Merr. & Củ đậu & 0.19 & $\mathrm{C}$ & Tuber & Food \\
\hline Pueraria phaseoloides Benth.* & Sắn dây & 0.33 & $\mathrm{C}$ & Tuber & Food \\
\hline Sophora japonica L. * & Hoè & 0.21 & W,C & Flower, fruit & Drink \\
\hline Tephrosia candida DC. & Cốt khí & 0.16 & W,C & Whole plant & Firewood \\
\hline Vigna radiata (L.) Wilczek. & Đậu xanh & 0.42 & $\mathrm{C}$ & Fruit & Food \\
\hline Vigna unguiculata (L.) Walp. & Đậu đen & 0.45 & $\mathrm{C}$ & Fruit & Food \\
\hline Fagaceae & Họ Dẻ & & & & \\
\hline Castanopsis boisii Hickel \& Camus+ & Dẻ ăn quả & 0.14 & W & Fruit, stem & $\begin{array}{l}\text { Food, } \\
\text { construction }\end{array}$ \\
\hline Castanopsis indica A. DC+ & Cà ổi & 0.13 & $\mathrm{~W}$ & Stem & $\begin{array}{l}\text { Firewood, } \\
\text { construction }\end{array}$ \\
\hline $\begin{array}{l}\text { Lithocarpus pseudosundaicus (Hick. \& } \\
\text { A. Camus) A. Camus+ }\end{array}$ & Sồi xanh & 0.17 & W & Stem & Construction \\
\hline $\begin{array}{l}\text { Quercus platycacalyx Hick. \& A. } \\
\text { Camus+ }\end{array}$ & Dẻ cau & 0.12 & W & Stem & Construction \\
\hline Flacourtiaceae & Họ Mồng quân & & & & \\
\hline Flacourtia balansae Gagnep.+ & Mồng quân & 0.09 & $\mathrm{~W}$ & Fruit & Food \\
\hline Hamamelidaceae & Họ Sau sau & & & & \\
\hline Liquidambar formosana Hance & Sau sau & 0.26 & $\mathrm{~W}$ & Leaves, resin & Food, candles \\
\hline Juglandaceae & Họ Hồ đào & & & & \\
\hline Engelhardtia chrysolepsis Hance+ & Chẹo tía & 0.22 & $\mathrm{~W}$ & Stem & Firewood \\
\hline Pterocarya tonkinensis Dode & Cơi & 0.13 & $\mathrm{~W}$ & Leaves & Fishing \\
\hline Lamiaceae & Họ Hoa môi & & & & \\
\hline Acrocephalus indicus Kuntze & Nhân trần & 0.41 & W & Stem, leaves & Drink \\
\hline Mentha crispa $\mathrm{L}$. & Húng , & 0.53 & $\mathrm{C}$ & Leaves & Food \\
\hline Ocimum basilicum $\mathrm{L}$. & Húng quế & 0.42 & $\mathrm{C}$ & Leaves & Food \\
\hline Perilla frutescens Britton. & Tía tô & 0.57 & $\mathrm{C}$ & Leaves & Food \\
\hline Lauraceae & Họ Long não & & & & \\
\hline Actinodaphne obovata Blume+ & Song xanh & 0.65 & $\mathrm{~W}$ & Stem & Construction \\
\hline Beilschmiedia poilanei $\mathrm{H}$. Liou+ & Chắp & 0.04 & $\mathrm{~W}$ & Stem & Construction \\
\hline Beilschmiedia ferruginea $\mathrm{H}$. Liou+ & Chắp xanh & 0.16 & W & Stem & Construction \\
\hline Cinnamomun cassia Blume * & Quế & 0.50 & $\mathrm{~W}, \mathrm{C}$ & Bark & Spice \\
\hline Litsea cubeba Pers. * & Màng tang & 0.38 & W & Leaves, fruit & Spice \\
\hline Machilus bonii Lecomte+ & Kháo vàng & 0.40 & $\mathrm{~W}$ & Stem & Construction \\
\hline
\end{tabular}




\begin{tabular}{|c|c|c|c|c|c|}
\hline \multirow{2}{*}{$\begin{array}{l}\text { Scientific name } \\
\text { Phoebe paniculata Nees+ }\end{array}$} & \multicolumn{4}{|c|}{ Common name Use index Wild/Cultivated Part utilized } & \multirow{2}{*}{$\begin{array}{l}\text { Use } \\
\text { Construction }\end{array}$} \\
\hline & Kháo nước & 0.66 & W & Stem & \\
\hline Lecythidaceae & Lộc vừng & & & & \\
\hline Barringtonia acutangula (L.) Gaertn. & Lộc vừng & 0.04 & $\mathrm{~W}, \mathrm{C}$ & Whole plant & Ornamental \\
\hline Lythraceae & Họ Sang lẻ & & & & \\
\hline Lagerstoemia calyculata Kurz+ & Sang lẻ & 0.81 & $\mathrm{~W}$ & Stem & Construction \\
\hline Magnoliaceae & Họ Ngọc Lan & & & & \\
\hline Michelia mediocris Dandy+ & Giổi xanh & 0.84 & $\mathrm{~W}$ & Seed, stem & $\begin{array}{l}\text { Spice, } \\
\text { construction }\end{array}$ \\
\hline Michelia tonkinensis A. Chev.+ & Giổi bắc bộ & 0.24 & W & Seed, stem & $\begin{array}{l}\text { Spice, } \\
\text { construction }\end{array}$ \\
\hline Manglietia conifera Dandy & Mõ & 0.32 & W,C & Stem & Construction \\
\hline Manglietia fordiana Oliver+ & Vàng tâm & 0.29 & W,C & Stem & Construction \\
\hline Melastomataceae & Họ Mua & & & & \\
\hline Melastoma normale D. Don * & Mua & 0.12 & W & Stem, fruit & Firewood, food \\
\hline Melastoma septemnervium Merr. & Mua đồi & 0.28 & W & Stem, fruit & Firewood, food \\
\hline Meliaceae & Họ Xoan & & & & \\
\hline Aphanamixis grandifolia Blume+ & Gội trắng & 0.53 & W & Stem & Construction \\
\hline $\begin{array}{l}\text { Aglaia spectabilis (Miq.) S.S. Jain \& } \\
\text { Bennet+ }\end{array}$ & Gội nếp & 0.56 & $\mathrm{~W}$ & Stem & Construction \\
\hline Chukrasia tabularis A. Juss. & Lát hoa & 0.52 & $\mathrm{~W}, \mathrm{C}$ & Stem & Construction \\
\hline Dysoxylum cauliflorum Hiern+ & Đinh hương & 0.78 & W & Stem & Construction \\
\hline Melia azedarach L. * & Xoan ta & 0.61 & $\mathrm{C}$ & Stem & Construction \\
\hline Mimosaceae & Họ Trinh nữ & & & & \\
\hline $\begin{array}{l}\text { Acacia auriculaeformis A. Cunn. ex } \\
\text { Benth. }\end{array}$ & Keo lá tràm & 0.90 & $\mathrm{C}$ & Stem & $\begin{array}{l}\text { Construction, } \\
\text { paper, firewood }\end{array}$ \\
\hline Acacia mangium Willd. & Keo Tai tượng & 0.87 & $\mathrm{C}$ & Stem & $\begin{array}{l}\text { Construction, } \\
\text { paper, firewood }\end{array}$ \\
\hline Moraceae & Họ Dâu tằm & & & & \\
\hline Antiaris toxicaria Lesch.+ & Sui & 0.31 & $\mathrm{~W}$ & Bark, stem & $\begin{array}{l}\text { Twine, } \\
\text { firewood }\end{array}$ \\
\hline Artocarpus heterophyllus Lam. & Mít & 0.65 & $\mathrm{C}$ & Fruit, stem & Food, firewood \\
\hline Artocarpus tonkinensis A. Chev. * & Chay & 0.16 & W,C & Fruit, bark & $\begin{array}{l}\text { Food, to chew } \\
\text { betel }\end{array}$ \\
\hline Broussonetia papyrifera Vent. * & Dướng & 0.07 & W & Leaves, stem & $\begin{array}{l}\text { Firewood, } \\
\text { twine }\end{array}$ \\
\hline Ficus auriculata Lour. *+ & Vả & 0.23 & W & Fruit, stem & Food, firewood \\
\hline Morus alba L. & Dâu tằm & 0.22 & $\mathrm{C}$ & Fruit & Food \\
\hline Myrsinaceae & Họ Đơn nem & & & & \\
\hline Embelia laeta $\mathrm{Mez}$ & Ngút trắng & 0.19 & $\mathrm{~W}$ & Leaves & Food \\
\hline Embelia oblongifolia (Benth.) Hemsl. & Chua ngút lá dài & 0.10 & $\mathrm{~W}$ & Leaves & Food \\
\hline Maesa balansae Mez & Đơn nem & 0.11 & $\mathrm{~W}$ & Leaves & Food \\
\hline Myrtaceae & Họ Sim & & & & \\
\hline Baeckea frutescens $\mathrm{L}$. & Thanh Hao & 0.09 & $\mathrm{~W}$ & Whole plant & $\begin{array}{l}\text { Brooms, } \\
\text { firewood }\end{array}$ \\
\hline $\begin{array}{l}\text { Cleistocalyx operculatus Merr. \& L.M. } \\
\text { Perry }\end{array}$ & Trâm vối & 0.19 & $\mathrm{~W}$ & Leaves & Drink \\
\hline Eucalyptus camaldulensis Dehnh.* & Bạnh đàn trắng & 0.58 & $\mathrm{C}$ & Stem & $\begin{array}{l}\text { Construction, } \\
\text { firewood, } \\
\text { paper }\end{array}$ \\
\hline Psidium guajava L. * & Ổi & 0.68 & $\mathrm{C}$ & Fruit & Food \\
\hline Rhodomyrtus tomentosa Hassk. * & Sim & 0.38 & $\mathrm{~W}$ & Fruit & Food \\
\hline Syzygium polyanthum Walp.+ & Sắn thuyền & 0.28 & W & Leaves & Food \\
\hline Olacaceae & Họ Bù Khai & & & & \\
\hline Erythropalum scandens Blume & Bù Khai & 0.37 & $\mathrm{~W}$ & Leaves & Food \\
\hline Opiliaceae & Họ Rau sắng & & & & \\
\hline Meliantha suavis Pierre+ & Rau sắng & 0.58 & $\mathrm{~W}$ & Leaves & Food \\
\hline
\end{tabular}




\begin{tabular}{|c|c|c|c|c|c|}
\hline Scientific name & Common name & Jse index & Wild/Cultivated & Part utilized & Use \\
\hline Oxalidaceae & Họ Chua me & & & & \\
\hline Oxalis corniculata L. * & Chua me & 0.25 & W & Whole plant & Food \\
\hline Piperaceae & Hồ tiêu & & & & \\
\hline Piper betle L.* & Trầu không & 0.53 & $\mathrm{C}$ & Leaves & Chewing betel \\
\hline Piper lolot C. DC. * & Lá lốt & 0.96 & $\mathrm{~W}, \mathrm{C}$ & Leaves & Food \\
\hline Rhamnaceae & Họ Táo & & & & \\
\hline Ziziphus mauritiana Lam. * & Táo nhà & 0.92 & $\mathrm{C}$ & Fruit & Food \\
\hline Ziziphus oenoplia (L.) Mill. & Táo rừng & 0.42 & $\mathrm{~W}$ & Fruit & Food \\
\hline Rosaceae & Họ Hoa Hồng & & & & \\
\hline Rubus alcaefolius Poir. & Mân xôi & 0.60 & W & Fruit & Food \\
\hline Rubus cochinchinensis Tratt. * & Ngấy & 0.36 & $\mathrm{~W}$ & Fruit & Food \\
\hline Rutaceae & Họ Cam & & & & \\
\hline Acronychia pedunculata Miq. & Bưởi bung & 0.53 & W & Fruit & Food \\
\hline Clausena dunniana H.Lev. + & Hồng bì rừng & 0.36 & W & Fruit & Food \\
\hline Clausena indica Oliver+ & Mắc mật & 0.33 & $\mathrm{~W}$ & Fruit & Food \\
\hline Clausena lansium Skeels *+ & Hồng bì & 0.19 & $\mathrm{C}$ & Fruit & Food \\
\hline Citrus aurantifolia Swingle & Chanh & 0.95 & $\mathrm{C}$ & Fruit, leaves & Food \\
\hline Citrus maxima Osbeck & Bưởi & 0.81 & $\mathrm{C}$ & Fruit & Food \\
\hline Citrus sinensis Osbeck & Cam & 0.79 & $\mathrm{C}$ & Fruit & Food \\
\hline Sapindaceae & Họ Bồ hòn & & & & \\
\hline Dimorcarpus longan Lour. & Nhãn & 0.96 & $\mathrm{C}$ & Fruit & Food \\
\hline Litchi chinensis Sonn. & Vải & 0.95 & $\mathrm{C}$ & Fruit & Food \\
\hline Amesiodendron chinense (Merr.) $\mathrm{Hu}+$ & Trường Sâng & 0.56 & $\mathrm{~W}$ & Stem & Construction \\
\hline Mischocarpus pentapetalus Radlk.+ & Trường kẹn & 0.15 & $\mathrm{~W}$ & Stem & Construction \\
\hline Pavieasia annamensis Pierre+ & Trường mật & 0.85 & $\mathrm{~W}$ & Stem & Construction \\
\hline $\begin{array}{l}\text { Sapotaceae } \\
\text { Achras sapota } \mathrm{L} .\end{array}$ & Ho Hông xiêm & & & & \\
\hline & $\begin{array}{l}\text { Hông xiêm } \\
\text { Vú sữa }\end{array}$ & 0.19 & $\mathrm{C}$ & Fruit & Food \\
\hline $\begin{array}{l}\text { Chrysophyllum cainito L. } \\
\text { Pouteria sapota (Jaca.) H. E Moore \& }\end{array}$ & $\begin{array}{l}\text { Vú sữa } \\
\text { Trúng à̀ }\end{array}$ & 0.20 & $\mathrm{C}$ & Fruit & Food \\
\hline $\begin{array}{l}\text { Pouteria sapota (Jacq.) H. E. Moore \& } \\
\text { Stearn. }\end{array}$ & I rưng ga & 0.50 & $\mathrm{C}$ & Fruit & Food \\
\hline Theaceae & Họ Chè & & & & \\
\hline Camellia amplexicaulis Cohen-Stuart+ & Hải đường & & & Whole plant & Ornamental \\
\hline Camellia sinensis Kuntze * & Chè & 0.25 & $\mathrm{C}$ & Leaves & Drink \\
\hline Tiliaceae & Họ Đay & 0.94 & C & Leaves & Drınk \\
\hline Microcos paniculata L.+ & Cò ke & 016 & W & Stem & Firewood \\
\hline Ulmaceae & Họ Du & 0.10 & w & stem & rilewood \\
\hline Trema orientalis (L.) Blume * & Hu đay & & & & \\
\hline Monocotyledons & Lớp Hành & 0.22 & W & Stem & Firewood \\
\hline Alliaceae & Họ Hành & & & & \\
\hline Allium fistulosum L. * & Hành & & & & \\
\hline Allium sativum L. * & Tỏi & 0.99 & $\mathrm{C}$ & Whole plant & Spice, food \\
\hline Arecaceae & Họ Cau Dừa & 1.00 & $\mathrm{C}$ & Whole plant & Spice, food \\
\hline Areca catechu L. * & $\mathrm{Cau}$ & 0.56 & $\mathrm{C}$ & Fruit, stem & Chewing betel, \\
\hline Calamus balansaeanus Becc. & Mây nước & & & & firewood \\
\hline Calamus faberi Becc. & Mây thủ công & 0.36 & W & Stem & Handicrafts \\
\hline Calamus platyacanthus Warb. ex Becc. & Song mật & 0.19 & W & Stem & Handicrafts \\
\hline Calamus tetradactylus Hance & Mây mật & 0.36 & W & Stem & Handicrafts \\
\hline Caryota mitis Lour. * & Đùng đình & 0.79 & $\mathrm{~W}$ & Stem & Handicrafts \\
\hline & & 0.21 & W & Stem & Handicrafts, \\
\hline Cocos nucifera $\mathrm{L}$ & Dừa & & & & food \\
\hline Daemonorops longispathus Becc. & Hèo & 0.67 & $\mathrm{C}$ & Fruit, stem & Food, firewood \\
\hline Livistona chinensis (Jacq.) R. Br. \& Mart. & Cọ & 0.38 & W & Stem & Handicrafts \\
\hline Costaceae & Họ Mía dò & 0.35 & $\mathrm{C}$ & Leaves, fruit & Oil, roofs \\
\hline Costus speciosus (Koenig) Smith & Mía dò & & & & \\
\hline Dioscoreaceae & Họ Củ nâu & 0.36 & W & Stem & Food \\
\hline
\end{tabular}




\begin{tabular}{|c|c|c|c|c|c|}
\hline \multirow{2}{*}{$\frac{\text { Scientific name }}{\text { Dioscorea cirrhosa Lour. } *}$} & \multicolumn{5}{|c|}{ Common name Use index Wild/Cultivated Part utilized Use } \\
\hline & Củ nâu & 0.34 & W & Tuber & Food \\
\hline Dioscorea persimilis Prain \& Burk * & Củ mài & 0.19 & W & Tuber & $\begin{array}{l}\text { Food, } \\
\text { to plaster board }\end{array}$ \\
\hline Marantaceae & Họ Lá Dong & & & & \\
\hline $\begin{array}{l}\text { Phrynium placentarium (Lour.) Merr. } \\
\text { Musaceae }\end{array}$ & $\begin{array}{l}\text { Lá dong } \\
\text { Ho Chuối }\end{array}$ & 0.95 & $\mathrm{~W}$ & Leaves & Wrapping cakes \\
\hline Musa basjoo Sieb. & Chuối ngự & 0.97 & $\mathrm{C}$ & $\begin{array}{l}\text { Fruit, flower } \\
\text { bud, stem }\end{array}$ & Food \\
\hline Musa balbisiana Colla & Chuối hột & 0.39 & $\mathrm{C}$ & $\begin{array}{l}\text { Fruit, flower } \\
\text { bud, stem }\end{array}$ & Food \\
\hline Musa acuminata Colla & Chuối rừng & 0.21 & $\mathrm{~W}$ & $\begin{array}{l}\text { Fruit, flower } \\
\text { bud, stem }\end{array}$ & Food \\
\hline Musa paradisiaca $\mathrm{L}$. & Chuối tiêu & 0.94 & $\mathrm{C}$ & $\begin{array}{l}\text { Fruit, flower } \\
\text { bud, stem }\end{array}$ & Food \\
\hline Orchidacea & Họ Phong lan & & & & \\
\hline Cymbidium lowianum Reichb.f. & Phong lan & 0.06 & $\mathrm{~W}$ & Whole plant & Ornamental \\
\hline Dendrobium aloideum La Llave \& Lex. & Hoàng thảo & 0.01 & $\mathrm{~W}$ & Whole plant & Ornamental \\
\hline Phormiaceae & Họ Hương bài & & & & \\
\hline Dianella nemorosa Lam. * & Hương bài & 0.04 & $\mathrm{~W}$ & Whole plant & Incense \\
\hline Poaceae & Họ Cỏ & & & & \\
\hline Arundinaria sat Balansa & Sặt & 0.50 & $\mathrm{~W}$ & Stem & Firewood \\
\hline Bambusa blumeana Schult. f. & Tre gai & 0.41 & $\mathrm{C}$ & Stem, shoot & $\begin{array}{l}\text { Construction, } \\
\text { food, tools }\end{array}$ \\
\hline Cymbopogon citratus Stapf* & Sả & 0.51 & $\mathrm{C}$ & Tuber & Food \\
\hline Dendrocalamus barbatus Hsueh \& D.Z.Li & Luồng & 0.78 & $\mathrm{C}$ & Stem, shoot & $\begin{array}{l}\text { Paper, } \\
\text { construction, } \\
\text { food, tools }\end{array}$ \\
\hline Indosasa angustata McClure & Vầu đắng & 0.37 & $\mathrm{~W}$ & Stem, shoot & $\begin{array}{l}\text { Food, } \\
\text { construction }\end{array}$ \\
\hline Indosasa sinica C.D. Chu \& C.S.Chao & Vầu ngọt & 0.33 & $\mathrm{~W}$ & Stem, shoot & $\begin{array}{l}\text { Food, } \\
\text { construction }\end{array}$ \\
\hline Panicum miliaceum L. & Kê & 0.36 & $\mathrm{C}$ & Seed & Food \\
\hline Saccharum officinarum L. & Mía & 0.96 & $\mathrm{C}$ & Stem & Food \\
\hline Schizostachyum funghomii McClure & Nứa & 0.99 & W & Stem, shoot & $\begin{array}{l}\text { Paper, food, } \\
\text { tools }\end{array}$ \\
\hline Zingiberaceae & Họ Gừng & & & & \\
\hline Curcuma longa L.* & Nghệ & 0.97 & $\mathrm{C}$ & Tuber, leaves & Spice, food \\
\hline Curcuma zedoaria Rosc.* & Nghệ đen & 0.39 & W,C & Tuber & Spice, food \\
\hline Zingiber officinale Rosc. * & Gừng & 0.99 & $\mathrm{C}$ & Tuber & Spice, food \\
\hline
\end{tabular}

Wild/Cultivated: $\mathrm{W}=$ Wild, $\mathrm{C}=$ Cultivated.

*Species are also use for medicinal plant purposes (see Hoang et al. 2008a).

+ Species recorded in plots. 
ApPendix 2. COMMERCIAL USEFUl PLANT SPECIES IN BEN EN NATIONAL PARK.

\begin{tabular}{|c|c|c|c|c|c|}
\hline Scientific name & $\begin{array}{l}\text { Abundance } \\
\text { in the wild } \\
\text { or cultivated }\end{array}$ & $\begin{array}{l}\text { Intensity of } \\
\text { collection }\end{array}$ & Price in US\$ & $\begin{array}{c}\text { Income/ } \\
\text { household/ } \\
\text { year } \\
\text { in US\$ }\end{array}$ & $\begin{array}{l}\text { Market } \\
\text { demand }\end{array}$ \\
\hline \multicolumn{6}{|l|}{ Anacar diaceae } \\
\hline $\begin{array}{l}\text { Dracontomelon dao (Blanco) Merr. } \\
\text { \& Rolfe }\end{array}$ & Cultivated & & Not stable & 0.5 & Medium \\
\hline Mangifera indica $\mathrm{L}$. & Cultivated & & $0.07 / 2$ fruits & 0.6 & Medium \\
\hline Spondias lakoensis Pierre & Cultivated & & Not stable & 0.1 & Medium \\
\hline \multicolumn{6}{|l|}{ Annonaceae } \\
\hline $\begin{array}{l}\text { Annona squamosa } \mathrm{L} . \\
\text { Araliaceae }\end{array}$ & Cultivated & & $0.07 / 3$ fruits & 0.6 & Medium \\
\hline Schefflera alpina Grushv. \& Skvorts. & High & Medium & Not stable & 0.2 & Medium \\
\hline \multicolumn{6}{|l|}{ Burseraceae } \\
\hline Canarium tonkinensis L. & Medium & High & $1.3 / \mathrm{kg}$ resin & 1.2 & High \\
\hline Canarium album Rauesch. & Medium & High & $\begin{array}{l}0.07 / \mathrm{kg} \text { fruit } \\
1.3 / \mathrm{kg} \text { resin }\end{array}$ & 2.9 & $\begin{array}{l}\text { Medium } \\
\text { High }\end{array}$ \\
\hline $\begin{array}{l}\text { Canarium tramdenum Dai \& Yakovlev } \\
\text { Caesalpiniaceae }\end{array}$ & Medium & High & $1.3 / \mathrm{kg}$ resin & 1.1 & High \\
\hline $\begin{array}{l}\text { Gleditsia australis Hemsl. ex Forb. } \\
\text { \& Hemsl. }\end{array}$ & Low & Medium & $0.07 / 4$ fruits & 0.2 & Medium \\
\hline $\begin{array}{l}\text { Tamarindus indica } \mathrm{L} . \\
\text { Clusiaceae }\end{array}$ & Low & High & $0.07 / 6$ fruits & 0.2 & Medium \\
\hline Garcinia cowa Roxb. & Low & Medium & $0.07 / 5$ fruits & 0.5 & Medium \\
\hline $\begin{array}{l}\text { Garcinia multiflora Champ. ex Benth. } \\
\text { Ebenaceae }\end{array}$ & Medium & Medium & $0.07 / 4$ fruits & 0.8 & Medium \\
\hline Diospyros decandra Lour. & Cultivated & & $0.07 / 6$ fruits & 0.8 & Medium \\
\hline Diospyros kaki L.f. & Cultivated & & $0.07 / 6$ fruits & 1.0 & Medium \\
\hline \multicolumn{6}{|l|}{ Euphorbiaceae } \\
\hline \multicolumn{5}{|l|}{ Lamiaceae } & Medium \\
\hline Acrocephalus indicus Kuntze & Medium & Medium & Not stable & 0.2 & Medium \\
\hline Moraceae & & & Not stable & 0.2 & Medium \\
\hline Artocarpus tonkinensis A. Chev. & Medium & High & & & \\
\hline \multicolumn{6}{|l|}{ Myrtaceae } \\
\hline Baeckea frutescens $\mathrm{L}$. & Medium & Medium & Not stable & 0.3 & Medium \\
\hline \multicolumn{6}{|l|}{ Olacaceae } \\
\hline \multicolumn{6}{|l|}{ Opiliaceae } \\
\hline Meliantha suavis Pierre & High & Medium & $0.14 / \mathrm{kg}$ & 0.5 & Medium \\
\hline \multicolumn{6}{|l|}{ Rutaceae } \\
\hline Citrus aurantifolia Swingle & Cultivated & & $0.07 / 5$ fruits & 0.5 & Medium \\
\hline Citrus maxima Osbeck & Cultivated & & $0.14 /$ fruits & 0.6 & Medium \\
\hline Citrus sinensis Osbeck & Cultivated & & $0.07 / 3$ fruits & 0.8 & Medium \\
\hline \multicolumn{6}{|l|}{ Sapotaceae } \\
\hline Achras sapota $\mathrm{L}$. & Cultivated & & $0.07 / 5$ fruits & 0.5 & Medium \\
\hline Chrysophyllum cainito $\mathrm{L}$. & Cultivated & & $0.07 / 5$ fruits & 0.7 & Medium \\
\hline Pouteria sapota (Jacq.) H. E. Moore & Cultivated & & $0.07 / 5$ fruits & 0.8 & Medium \\
\hline
\end{tabular}




\begin{tabular}{|c|c|c|c|c|c|}
\hline Scientific name & $\begin{array}{l}\text { Abundance } \\
\text { in the wild } \\
\text { or cultivated }\end{array}$ & $\begin{array}{l}\text { Intensity of } \\
\text { collection }\end{array}$ & Price in US\$ & $\begin{array}{c}\text { Income/ } \\
\text { household/ } \\
\text { year } \\
\text { in US\$ } \\
\end{array}$ & $\begin{array}{r}\text { Market } \\
\text { demand }\end{array}$ \\
\hline \multicolumn{6}{|l|}{$\begin{array}{l}\text { Liliopsida } \\
\text { Arecaceae }\end{array}$} \\
\hline Calamus balansaeanus Becc. & Low & Medium & $0.17 / \mathrm{kg}$ & 1.0 & Medium \\
\hline Calamus faberi Becc. & Low & Medium & $0.17 / \mathrm{kg}$ & 1.2 & Medium \\
\hline $\begin{array}{l}\text { Calamus tetradactylus Hance } \\
\text { Dioscoreaceae }\end{array}$ & Low & Medium & $0.17 / \mathrm{kg}$ & 2.6 & Medium \\
\hline Dioscorea cirrhosa Lour. & High & Low & Not stable & 0.3 & Low \\
\hline $\begin{array}{l}\text { Dioscorea persimilis Prain \& Burk } \\
\text { Marantaceae }\end{array}$ & High & Low & Not stable & 0.4 & Low \\
\hline Phrynium placentarium (Lour.) Merr. & High & Medium & $\begin{array}{l}0.28 / 100 \\
\text { leaves }\end{array}$ & 2.7 & Medium \\
\hline \multicolumn{6}{|l|}{ Poaceae } \\
\hline Indosasa sibata C.D.Chu \& C.S.Chao & Medium & High & $\begin{array}{l}0.2 / \text { fresh kg } \\
\text { (Bamboo } \\
\text { shoot) }\end{array}$ & 2.0 & High \\
\hline Indosasa sibataeooides McClure & Medium & High & $\begin{array}{l}0.2 / \text { fresh kg } \\
\text { (Bamboo } \\
\text { shoot) }\end{array}$ & 1.8 & High \\
\hline Schizostachyum funghomii McClure & High & High & $\begin{array}{l}1.1 / \text { dried, } \\
0.17 \text { fresh kg } \\
\text { (Bamboo } \\
\text { shoot) } \\
0.0014 / \text { trees }\end{array}$ & 13 & High \\
\hline
\end{tabular}

